\title{
Russ Chinese
}

National Cancer Institute

\section{Source}

National Cancer Institute. Russ Chinese. NCI Thesaurus. Code C158204.

A Chinese person from the Russ ethnic group. 